\title{
Aurora Kinase B
}

National Cancer Institute

\section{Source}

National Cancer Institute. Aurora Kinase B. NCI Thesaurus. Code C68596.

Aurora kinase B (344 aa, $39 \mathrm{kDa}$ ) is encoded by the human AURKB gene. This protein plays a role in both the modulation of microtubule structure and facilitation of chromosome segregation during mitosis and meiosis. 